\title{
COVID-19 propagation mathematical modeling: the case of Senegal
}

\author{
Mouhamadou Diaby ${ }^{1}$, Oumar Diop ${ }^{1}$, Almamy Konté ${ }^{3}$, Abdou Sène ${ }^{1,2}$ \\ ${ }^{1}$ UVS, Université Virtuelle du Sénégal \\ LANI, Laboratoire d'Analyse Numérique et d'Informatique \\ Dakar, Sénégal \\ mouhamadou.diaby@uvs.edu.sn, oumar.diop@uvs.edu.sn \\ ${ }^{2}$ UVS, Université Virtuelle du Sénégal \\ PIED, Pôle d'Innovation et d'Expertise pour le Développement \\ Dakar, Sénégal \\ abdou.sene@uvs.edu.sn \\ ${ }^{3}$ AOSTI-African Union Commission \\ Faculté des Sciences et Techniques, Université Cheikh Anta Diop de Dakar \\ almamy.konte@ucad.edu.sn
}

Received: 1 July 2020, accepted: 3 September 2020, published: 10 September 2020

\begin{abstract}
The outburst of the COVID-19 pandemic has raised several questions leading to a complex system in terms of modeling. Indeed, the modeling of the epidemic, at the level of a country, needs considering each of the different sources of contamination as well as the public health authorities strategy, in a specific way. With this in mind, in the present paper, we develop a mathematical model of the COVID-19 epidemic in Senegal. In the model, the population is subdivided into five compartments: susceptible, infected but asymptomatic, symptomatic, quarantined, and recovered immune people. In addition, due to its important impact in the propagation of the disease, we add one more variable: the number of infected objects. Therefore, the model corresponds to a system of six non-linear ordinary differential equations we submit to an
\end{abstract}

analytical study to prove the relevancy of the model, simulate the evolution of the epidemic, and retrieve epidemiological parameters, namely the infection rate and the basic reproduction number, $\mathcal{R}_{0}$. Based on the senegalese territory COVID-19 data, we simulate various scenarios as for the evolution of the epidemic in the country, in order to predict the peak and its magnitude with regard to the application of barrier measures. We also explore the option of collective immunity with special protection for vulnerable people. In doing so, non available parameters are identified using some mathematical identification technics.

Keywords-COVID-19; Mathematical model; Fitting strategy; Reproduction number.

Copyright: (c) 2020 Diaby at al. This article is distributed under the terms of the Creative Commons Attribution License (CC BY 4.0), which permits unrestricted use, distribution, and reproduction in any medium, provided the original author and source are credited.

Citation: Mouhamadou Diaby, Oumar Diop, Almamy Konté, Abdou Sène, COVID-19 propagation mathematical modeling: the case of Senegal, Biomath 9 (2020), 2009037, 
M. Diaby, O. Diop, A. Konté, A. Sène, COVID-19 propagation mathematical modeling: the case of ...

\section{INTRODUCTION}

Since December 2019, the World has been facing a very rapidly spreading pandemic, the COVID-19 due to a virus named SARS-CoV-2. Starting in Wuhan, China, the disease has almost reached the whole globe in less than 5 months. Despite the lack of full understanding of the pandemic, due to its novelty, a number of articles have been released, in mathematical modeling (see [5], [3], [6], [7], [8], [12], [13]) as well as in various factors of propagation of the virus (see [15], [2]). In the early days of the pandemic Liu et al in [5] have developed a COVID-19 propagation model taking into account, in addition to susceptible and asymptomatic compartments, a splitting of the symptomatic into two compartments: the identified and the non identified. They have also addressed other aspects of the pandemic such as the latency phenomenon related to COVID19 in [7]. As a crucial factor, age structure is addressed by Griette et al in [3], in the context of Japan. And, on another note, Ogbunugafor et al in [12] came up with a COVID-19 model which involves the contamination by infected objects. Moreover, numerous works have been done in the short period of time, which contribute to a better understanding of the COVID-19 propagation processes. For instance, the work of Doremalen et al in [2] gives a broad overview of the life expectancy of SARS-CoV-2 on different kinds of objects, and in the air. Their paper states that the virus' life expectancy cannot exceed: 72 hours on plastic, 48 hours on stainless steel, 24 hours on cardboard, 4 hours on copper. Such information is of capital importance for modeling the effects of contaminated objects in the propagation of the virus.

Two cornerstones in the contamination process by infected objects are also given by practical and natural human habits. They are Human $\mathrm{Ob}$ jects Touching (HOT) and Human Face Touching (HFT). These phenomena are studied in a book from Zuccotti, (see [17]) for HOT, and in a paper of Kwok et al in [10] for HFT. As for the influence of climate conditions like temperature and humidity, a study is already done by Wang et al in [15].

Relying on the relatively abundant literature, in view of the novelty of the COVID-19 pandemic and its virus, the present work presents a model which fits the epidemic management in Senegal. Indeed, the model complies with the different strategies adopted by the public health decisionmakers of Senegal. In that respect, we have considered a quarantined compartment and used the related daily data released by the authorities. The other compartments of the present model are quite classical apart from one. Indeed, in terms of human compartments, in addition to the quarantined people compartment, we consider the susceptibles, the asymptomatics, the symptomatics and the removed. The novelty in the present paper is the infected objects compartment we have added, and the way we consider newly contaminated objects by properly defining the coefficients. This is critical in avoiding redundancy while counting the contaminated objects.

As for the organization of the paper, after the present introduction, we present the model in detail in Section 2. Then, we do some qualitative analysis in Section 3 to verify the boundedness of the infected objects variable, calculate $\mathcal{R}_{0}$ and analyse its sensitivity. The fourth section is devoted to exploiting the data to retrieve the epidemic parameters such as the infectivity rate, and to simulating some scenarios with regard to compliance or not with barrier measures.

\section{DERIVATION OF THE MODEL}

The mathematical model discussed in this paper is a system of 6 nonlinear differential equations. The variables are defined in the following table.

\begin{tabular}{|l|l|}
\hline Variables & Descriptions \\
\hline$S$ & Susceptible population \\
\hline$E$ & Infected asymptomatic population \\
\hline$C$ & Quarantined population \\
\hline $\mathcal{I}$ & Infected symptomatic population \\
\hline $\mathcal{I} x$ & Infected objects \\
\hline$R$ & Immune recovered population \\
\hline
\end{tabular}


M. Diaby, O. Diop, A. Konté, A. Sène, COVID-19 propagation mathematical modeling: the case of ...

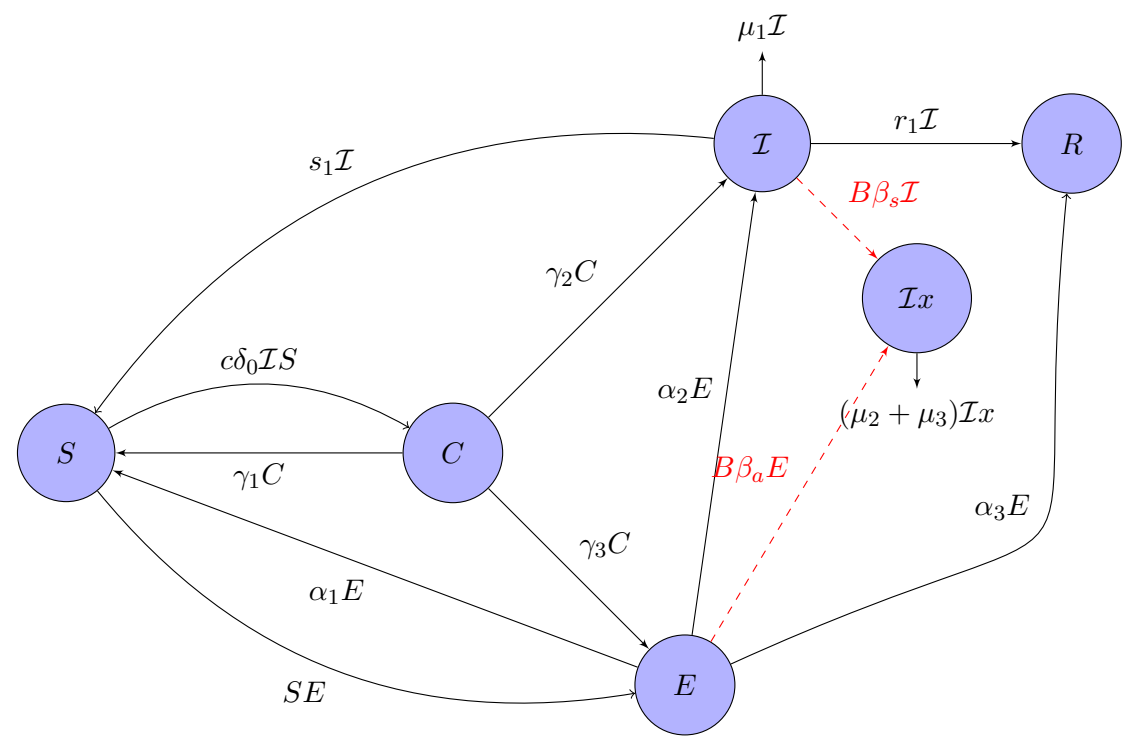

Flow chart of the model, where $\gamma_{1}=\left(1-\delta^{c i} / c\right) / 14, \gamma_{2}=(1-r a) \delta^{c i} /(3 c), \gamma_{3}=r a \delta^{c i} /(3 c)$, $S E=\left(1-\delta_{0}\right) \delta^{c i} \mathcal{I}+\delta^{x} \mathcal{I} x+\delta^{e} E, B=B\left(1-\frac{\mathcal{I} x}{B_{s} \mathcal{I}+B_{a} E}\right)$.

- The infection rates $\delta^{c i}, \delta^{e}$ and $\delta^{x}$, as well as the daily human number of contacts, $c$, are fitted to comply with the epidemiological data such as quarantined and under treatment subjects. Note that, due to the results of a recent survey initiated by the Center for Global Development (CGD, https://www.cgdev.org) and the Centre de recherche pour le développement économique et social (CRDES, http://crdes.sn), and led by A. Nestour, S. Mbaye and L. Moscoviz (see [11]), after the fitting, the mean value of $c$ is supposed to be 10 . In fact, the survey says that the average number of human contacts per capita per day is 10 .

- As for the infected objects parameters, we assume that positive asymptomatics and symptomatics infect on average 20 and 5 objects per day respectively; and that the maximum number of objects per day they can infect is 400 and 100 respectively. Some references about objects touching by humans can be found in the book of P. Zuccotti [17].
For the sake of clarity, each of the terms of the model is numbered and is explained below.

$$
\begin{aligned}
\frac{d S}{d t}= & -c \delta_{0}{ }^{(1)} \mathcal{I} S-\left[\left(1-\delta_{0}\right) \delta^{c i} \mathcal{I}+\delta^{x} \mathcal{I} x+\delta^{e} E\right] S \\
& +\left(1-\delta^{c i} / c\right) / 14 C+{ }^{(3)}{ }^{(6)} \mathcal{I}+{ }^{(7)} \alpha_{1} E,
\end{aligned}
$$

$$
\begin{aligned}
\frac{d E}{d t}= & {\left[\left(1-\delta_{0}\right) \delta^{c i} \mathcal{I}+\delta^{x} \mathcal{I} x+\delta^{e} E\right] S } \\
& +\operatorname{ra\delta }^{c i} /(5)(3 c) C-\left(\alpha_{1}+\alpha_{2}+\alpha_{3}\right) E,
\end{aligned}
$$

$$
\frac{d C}{d t}=c \delta_{0}^{(1)} \mathcal{I} S-\left[\left(1-\delta^{c i} / c\right) / 14+\delta^{c i} /(3 c)\right] C,
$$$$
\frac{d \mathcal{I}}{d t}={ }^{(8)} E+(1-r a){ }^{(4)} \delta^{c i} /(3 c) C-{ }_{r}{ }_{1} \mathcal{I}
$$

$$
\begin{gathered}
{ }^{(6)} \\
-s_{1} \mathcal{I}-\mu_{1} \mathcal{I},
\end{gathered}
$$$$
\frac{d R}{d t}={ }^{(10)} \mathcal{I}+\alpha_{3} E \text {. }
$$

- (1) stands for people who are identified to have been in contact with infected people, and quarantined. 
M. Diaby, O. Diop, A. Konté, A. Sène, COVID-19 propagation mathematical modeling: the case of ...

Parameter values estimated

\begin{tabular}{|l|l|l|}
\hline Parameters & Descriptions & Daily values \\
\hline$\delta_{0}$ & Identification rate of infected people & 0.7 \\
\hline$r a$ & Estimated rate of asymptomatics & 0.9 \\
\hline$\delta^{c i}$ & Infection rate of susceptibles by symptomatics & Fitting \\
\hline$\delta^{e}$ & Infection rate of susceptibles by asymptomatics & $0.25 * \delta^{c i}$ \\
\hline$\delta^{x}$ & Infection rate of susceptibles by infected objects & $0.01 * \delta^{c i}$ \\
\hline$\alpha_{1}$ & The rate asymptomatics step back to susceptibility & $1 / 1 \mathrm{e} 4^{*} \mathrm{ra} / 7$ \\
\hline$\alpha_{2}$ & The rate asymptomatics become symptomatic & $(1-\mathrm{ra}) / 7$ \\
\hline$\alpha_{3}$ & The rate asymptomatics become immune & $9999 / 1 \mathrm{e} 4 * \mathrm{ra} / 7$ \\
\hline$r_{1}$ & The rate symptomatics become immune & $1 / 7$ \\
\hline$s_{1}$ & The rate symptomatics step back to susceptibility & $1 / 1 \mathrm{e} 4^{*} r_{1}$ \\
\hline$\mu_{1}$ & The death rate of symptomatics & 0.0112 \\
\hline$\beta_{a}$ & Number of objects infected by one asymptomatic & 20 \\
\hline$\beta_{s}$ & Number of objects infected by one symptomatic & 5 \\
\hline$B_{a}$ & Maximum number of objects infected by one asymptomatic & 400 \\
\hline$B_{s}$ & Maximum number of objects infected by one symptomatic & 100 \\
\hline$\mu_{2}$ & The average death rate of the SARS-CoV-2 on objects & $1 / 1$ \\
\hline$\mu_{3}$ & The decontamination rate of infected objects & 2 \\
\hline$c$ & The contact rate of humans & Fitting \\
\hline
\end{tabular}

- (2) stands for not identified susceptible people who become infected.

- (3) stands for people who have been quarantined and eventually proved not to be infected after 14 days.

- (4) stands for people who have been quarantined and eventually proved to be infected.

- (5) stands for people who have been quarantined and eventually proved to be infected but asymptomatic.

- (6) stands for people who have been symptomatic and who have eventually recovered but not immune.

- (7) stands for asymptomatic infected people who have recovered but are susceptible again.

- (8) stands for asymptomatic infected people who become symptomatic.

- (9) stands for asymptomatic infected people who become immune.

- (10) stands for symptomatic people who have eventually recovered and become immune.

- (11) stands for symptomatic people who have died from the disease.
In addition, we consider a compartment of infected objects $\mathcal{I} x$ in the model. That variable fed by the infected individuals is governed by the following ordinary differential equation:

$$
\begin{aligned}
\frac{d \mathcal{I} x}{d t}= & B\left(1-\frac{\mathcal{I} x}{B_{s} \mathcal{I}+B_{a} E}\right)\left[\stackrel{(12)}{\beta_{s} \mathcal{I}}+\stackrel{(}{\beta}_{a} E\right] \\
& -\left(\mu_{2}+\mu_{3}\right) \mathcal{I} x
\end{aligned}
$$

where $B$ is monotone increasing real continuous function defined on $[0,1]$ with range $[0,1]$ such that $B(0)=0$.

- (12) stands for the release of the viruses from symptomatic people.

- (13) stands for the release of the viruses from asymptomatic people.

- (14) stands for the death rate of the released viruses. This can be augmented, through $\mu_{3}$, by using biocides.

Parameters $B_{s}$ and $B_{a}$ are the maximum number of objects a symptomatic and positive asymptomatic can infect, respectively. 
M. Diaby, O. Diop, A. Konté, A. Sène, COVID-19 propagation mathematical modeling: the case of ...

Therefore, the term $B\left(1-\frac{\mathcal{I} x}{B_{s} \mathcal{I}+B_{a} E}\right)$ is intended to avoid counting recontamination of objects while they are infected. Notice that when $\mathcal{I} x$ increases up to $B_{s} \mathcal{I}+B_{a} E$, then it starts decreasing due to $\mu_{2}$ and $\mu_{3}$, the mortality and the decontamination rates of the SARS-CoV-2, respectively. The use of function $B$ has the merit of addressing the modeling of environmental contamination in a relatively more explicit way, compared to the models we have met (see [12], [1]).

It's also worth mentioning that the present model differs significantly from those (see [3], [5], [6], [7], [8], [16]) found in the literature and involving a quarantine compartment. Indeed, in our model, the quarantined people are not a priori qualified, that is, one does not know, contrary to the models we have met, wether the subjects in the quarantine compartment are infected or not. People in the present compartment $C$ may be uninfected, infected but asymptomatic or symptomatic. Such a definition of the quarantine compartment is in complete compliance with the Senegalese health authorities strategy.

\section{MAThematical ANALYSis OF THE MODEL}

A. Boundedness of the number of objects variable

For system (1)-(2), it is obviously that the solution is positive.

Proposition 1. Assume that for some time $t_{0}>0$, the infected objects and humans variables satisfy the following inequality.

$$
\mathcal{I} x\left(t_{0}\right)<B_{s} \mathcal{I}\left(t_{0}\right)+B_{a} E\left(t_{0}\right) .
$$

If the hypothesis

$$
\begin{aligned}
& \mu_{2}+\mu_{3}>1 \\
& \alpha_{1}+\alpha_{2}+\alpha_{3} \leq 1, \\
& r_{1}+s_{1}+\mu_{1} \leq 1
\end{aligned}
$$

holds, then

$$
\mathcal{I} x(t) \leq B_{s} \mathcal{I}(t)+B_{a} E(t), \quad \forall t \geq t_{0} .
$$

Proof. Suppose that there exists $t>t_{0}$ such that the following equality holds:

$$
B_{s} \mathcal{I}(t)+B_{a} E(t)=\mathcal{I} x(t)
$$

Let us now calculate the derivative of $B_{s} \mathcal{I}(t)+$ $B_{a} E(t)-\mathcal{I} x(t)$ at time $t$ :

$$
\begin{aligned}
B_{s} \frac{d \mathcal{I}}{d t} & +B_{a} \frac{d E}{d t}-\frac{d \mathcal{I} x}{d t} \\
= & B_{s} \alpha_{2} E+B_{s}(1-r a)\left(\delta^{c i} / c\right) C \\
& -B_{s}\left(r_{1}+s_{1}+\mu_{1}\right) \mathcal{I} \\
& +B_{a}\left(\left(1-\delta_{0}\right) \delta_{1}^{c i} \mathcal{I}+\delta^{x} \mathcal{I} x+\delta^{e} E\right) S \\
& +B_{a} r a \delta^{c i} /(3 c) C \\
& -B_{a}\left(\alpha_{1}+\alpha_{2}+\alpha_{3}\right) E+\left(\mu_{2}+\mu_{3}\right) \mathcal{I} x .
\end{aligned}
$$

Therefore, from hypothesis (3) and identities (5)(6), we obtain

$$
\begin{aligned}
B_{s} \frac{d \mathcal{I}}{d t} & +B_{a} \frac{d E}{d t}-\frac{d \mathcal{I} x}{d t} \\
\geq & B_{s} \alpha_{2} E+B_{s}(1-r a)\left(\delta^{c i} / c\right) C \\
& +B_{a}\left(\left(1-\delta_{0}\right) \delta_{1}^{c i} \mathcal{I}+\delta^{x} \mathcal{I} x+\delta^{e} E\right) S \\
& +B_{a} r a \delta^{c i} /(3 c) C \\
& +\left(\mu_{2}+\mu_{3}-1\right) \mathcal{I} x \geq 0
\end{aligned}
$$

case 1: $\mathcal{I} x(t)>0$

$$
B_{s} \frac{d \mathcal{I}}{d t}+B_{a} \frac{d E}{d t}-\frac{d \mathcal{I} x}{d t} \geq\left(\mu_{2}+\mu_{3}-1\right) \mathcal{I} x>0 .
$$

case 2: $\mathcal{I} x(t)=0$ and $C(t)>0$

$B_{s} \frac{d \mathcal{I}}{d t}+B_{a} \frac{d E}{d t}-\frac{d \mathcal{I} x}{d t} \geq B_{a} r a \delta^{c i} /(3 c) C>0$.

case 3: $\mathcal{I} x(t)=0$ and $C(t)=0$

If $\mathcal{I} x(t)=0$ then $\mathcal{I}(t)=E(t)=0$ due to 5 , then $\mathcal{I} x=\mathcal{I}=E=C=0$ for all time $t \geq t_{0}$.

We have proved that at any time $t>t_{0}$ where $B_{s} \mathcal{I}+B_{a} E-\mathcal{I} x=0$, its derivative is nonnegative. Consequently, inequality (4) is satisfied.

\section{B. The basic reproduction number}

The basic reproduction ratio $\mathcal{R}_{0}$, gives the average number of secondary cases of infection resulting from a single primary infection in a population where everyone is susceptible. In epidemic models, it is worthy of consideration as it is the indicator of persistence or eradication of diseases, by giving a threshold depending on epidemiological parameters. Indeed, an epidemic is said to be under control (cannot persist in the population) when $\mathcal{R}_{0}<1$. 
M. Diaby, O. Diop, A. Konté, A. Sène, COVID-19 propagation mathematical modeling: the case of ...

$$
\mathcal{R}_{0}=S_{0}\left[\frac{\alpha_{2} \beta_{s} \delta^{x}-\alpha_{2}\left(\delta_{0}-1\right) \delta^{c i}\left(\mu_{2}+\mu_{3}\right)+\left(\mu_{1}+r_{1}+s_{1}\right)\left(\beta_{a} \delta^{x}+\delta^{e}\left(\mu_{2}+\mu_{3}\right)\right)}{\left(\mu_{2}+\mu_{3}\right)\left(\alpha_{1}+\alpha_{2}+\alpha_{3}\right)\left(\mu_{1}+r_{1}+s_{1}\right)}\right],
$$

that is:

$$
\begin{aligned}
\mathcal{R}_{0} & =S_{0}\left[\frac{\alpha_{2}}{\alpha_{1}+\alpha_{2}+\alpha_{3}} \frac{\left(1-\delta_{0}\right) \delta^{c i}}{r_{1}+s_{1}+\mu_{1}}+\frac{\delta^{e}}{\alpha_{1}+\alpha_{2}+\alpha_{3}}\right] \\
& +S_{0}\left[\frac{\alpha_{2}}{\alpha_{1}+\alpha_{2}+\alpha_{3}} \frac{\beta_{s} \delta^{x}}{\left(\mu_{2}+\mu_{3}\right)\left(r_{1}+s_{1}+\mu_{1}\right)}+\frac{\beta_{a} \delta^{x}}{\left(\mu_{2}+\mu_{3}\right)\left(r_{1}+s_{1}+\mu_{1}\right)}\right] .
\end{aligned}
$$

In the expression of $\mathcal{R}_{0}$, the first two terms stand for the infections generated by asymptomatic and symptomatic humans, while the last two terms represent contamination caused by infected objects. With this expression, we can see that there are several ways to reduce $\mathcal{R}_{0}$. For example, this can be done by increasing $\mu_{3}$, the disinfection rate of infected objects, or by increasing the identification rate, $\delta_{0}$.

When a pandemic breaks out, an effective strategy should be developed so that the reproduction number reduces to less than 1 as soon as possible. So, sensitivity analysis is performed to investigate the parameters that exert the greatest influence on this ratio. In this study, we perform the partial rank correlation coefficient (PRCC), which is a global sensitivity analysis technique proven to be one of the most reliable. The sign of the PRCC suggests qualitative relationship between the parameters and $\mathcal{R}_{0}$. A positive value of the PRCC implies correlation between $\mathcal{R}_{0}$ and a parameter while negative value proves anti-correlation.

The following figure displays the correlation magnitude between $\mathcal{R}_{0}$ and the model parameters such as the transition rates $\alpha_{2}, \alpha_{2}, \alpha_{3}$, the transmission rates $\delta^{c i}, \delta^{e}, \delta^{x}$ and the average numbers of objects $\beta_{s}$ and $\beta_{a}$ that symptomatics and asymptomatics can infect per day respectively. The figure shows, in particular, that the magnitude of the correlation between the infection rate of objects $\beta_{a}$ and $\mathcal{R}_{0}$ is important enough to be taken into account in the expansion of COVID-19.

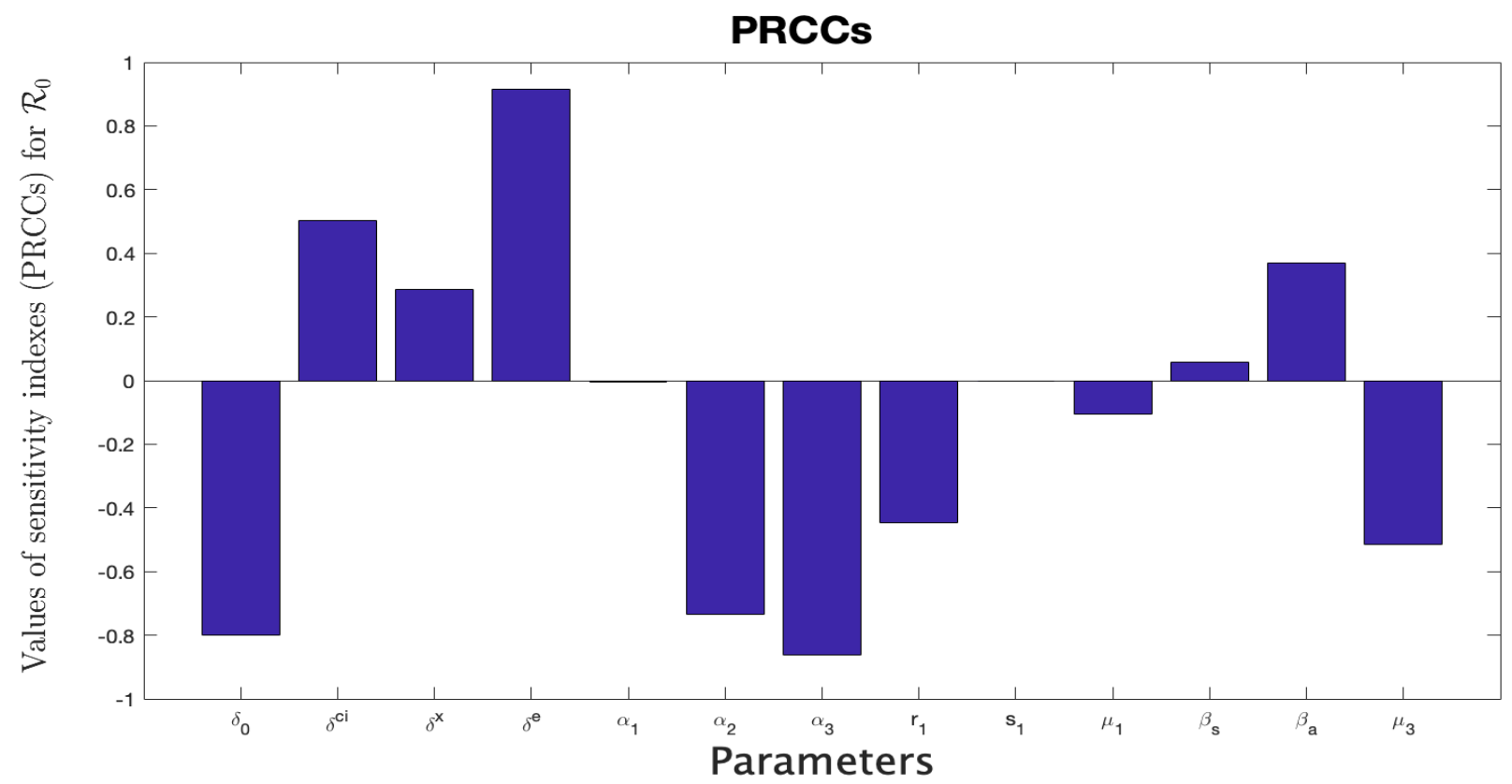


M. Diaby, O. Diop, A. Konté, A. Sène, COVID-19 propagation mathematical modeling: the case of ...

\section{NUMERICAL SIMULATIONS}

\section{A. Fitting procedure}

For the fitting process, let us consider the Euler discretization scheme:

$$
\begin{aligned}
& \text { a. } S^{k+1}=S^{k}+h\left(-c \delta_{0} \mathcal{I}^{k} S^{k}-\left[\left(1-\delta_{0}\right) \delta^{c i} \mathcal{I}^{k}+\delta^{x} \mathcal{I} x^{k}+\delta^{e} E^{k}\right] S^{k}\right. \\
&\left.+\left(1-\delta^{c i k} / c\right) / 14 C^{k}+s_{1} \mathcal{I}^{k}+\alpha_{1} E^{k}\right), \\
& \text { b. } \quad E^{k+1}=E^{k}+h\left(\left[\left(1-\delta_{0}\right) \delta^{c i} \mathcal{I}^{k}+\delta^{x} \mathcal{I} x^{k}+\delta^{e} E^{k}\right] S^{k}\right. \\
&\left.\quad+r a \delta^{c i k} /(3 c) C^{k}-\left(\alpha_{1}+\alpha_{2}+\alpha_{3}\right) E^{k}\right), \\
& \text { c. } \quad C^{k+1}=C^{k}+h\left(c \delta_{0} \mathcal{I}^{k} S^{k}-\left(\left(1-\delta^{c i k} / c\right) / 14+\delta^{c i} /(3 c)\right) C^{k}\right), \\
& \text { d. } \quad \mathcal{I}^{k+1}=\mathcal{I}^{k}+h\left(\left(-r_{1}-s_{1}-\mu_{1}\right) \mathcal{I}^{k}+\alpha_{2} E^{k}+(1-r a) \delta^{c i k} /(3 c) C^{k}\right), \\
& \text { e. } \quad \mathcal{I}^{k+1}=\mathcal{I}^{k}+h\left(B\left(1-\frac{\mathcal{I}^{k}}{B_{s} \mathcal{I}^{k}+B_{a} E^{k}}\right)\left[\beta_{s} \mathcal{I}^{k}+\beta_{a} E^{k}\right]-\mu_{3} \mathcal{I} x^{k}\right), \\
& \text { f. } \quad R^{k+1}=R^{k}+h\left(r_{1} \mathcal{I}^{k}+\alpha_{3} E^{k}\right) .
\end{aligned}
$$

The fitting algorithm we use in this work consists on utilizing the available daily data about the people under treatment, $\mathcal{I}_{f}$, and the quarantined individuals, $C_{f}$. Indeed, we impose to the latter to be solution of (8), from day 15 th to day 77 th. This fitting allows to estimate the social and epidemiological data such as the average number of contacts per person per day and the probability to be infected when in contact with an infected person. Assume that the identification rate $\delta_{0}$ is known. Then, with the infectivity rate denoted by $\delta^{c i}=c \beta^{c i}$, the fitting system is

$$
\begin{aligned}
& \text { a. } \quad S^{k+1}=S^{k}+h\left(-c^{k} \delta_{0} \mathcal{I}_{f}^{k} S^{k}-\left[\left(1-\delta_{0}\right) \delta^{c i}{ }^{k} \mathcal{I}_{f}^{k}+\delta^{x} \mathcal{I} x^{k}+\delta^{e} E^{k}\right] S^{k}\right) \\
& +h\left(\left(1-\beta^{c i k}\right) / 14 C_{f}^{k}+s_{1} \mathcal{I}_{f}^{k}+\alpha_{1} E^{k}\right) \\
& \text { b. } E^{k+1}=E^{k}+h\left(\left[\left(1-\delta_{0}\right) \delta^{c i} \mathcal{I}_{f}^{k}+\delta^{x} \mathcal{I} x^{k}+\delta^{e} E^{k}\right] S^{k}\right) \\
& +h\left(r a / 3 \beta^{c i k} C_{f}^{k}-\left(\alpha_{1}+\alpha_{2}+\alpha_{3}\right) E^{k}\right) \\
& \text { c. } \quad C_{f}^{k+1}=C_{f}^{k}+h\left(c^{k} \delta_{0} \mathcal{I}_{f}^{k} S^{k}-\left(\left(1-\beta^{c i k}\right) / 14+\beta^{c i k} / 3\right) C_{f}^{k}\right) \\
& \text { d. } \quad \mathcal{I}_{f}^{k+1}=\mathcal{I}_{f}^{k}+h\left(\left(-r_{1}-s_{1}-\mu_{1}\right) \mathcal{I}_{f}^{k}+\alpha_{2} E^{k}+(1-r a) / 3 \beta^{c i}{ }^{k} C_{f}^{k}\right)
\end{aligned}
$$


M. Diaby, O. Diop, A. Konté, A. Sène, COVID-19 propagation mathematical modeling: the case of ...

$$
\begin{aligned}
& \text { e. } \quad \mathcal{I}^{k+1}=\mathcal{I} x^{k}+h\left(B\left(1-\frac{\mathcal{I} x^{k}}{B_{s} \mathcal{I}^{k}+B_{a} E^{k}}\right)\left[\beta_{s} \mathcal{I}_{f}^{k}+\beta_{a} E^{k}\right]-\mu_{3} \mathcal{I} x^{k}\right) \\
& f . \quad R^{k+1}=R^{k}+h\left(r_{1} \mathcal{I}_{f}^{k}+\alpha_{3} E^{k}\right),
\end{aligned}
$$

where $c^{k}$ and $\beta^{c i}{ }^{k}$ are calculated from equations 9$)_{c, d}$, say

$$
\begin{aligned}
c^{k} & =\frac{1}{\delta_{0}{ }^{k} \mathcal{I}_{f}{ }^{k} S^{k}}\left(\frac{C_{f}^{k+1}-C_{f}^{k}}{h}+\left(\left(1-\beta^{c i k}\right) / 14+\beta^{c i k} / 3\right) C_{f}^{k}\right), \\
\beta^{c i} k & =\frac{3}{(1-r a) C_{f}^{k}}\left(\frac{\mathcal{I}_{f}^{k+1}-\mathcal{I}_{f}^{k}}{h}+\left(r_{1}+s_{1}+\mu_{1}\right) \mathcal{I}_{f}^{k}-\alpha_{2} E^{k}\right) .
\end{aligned}
$$

The fitting results and the simulation being tightly related to Senegalese authorities strategies to fight

\begin{tabular}{|c|c|}
\hline Date & Measures \\
\hline 22 January 2020 & $\begin{array}{l}\text { - First communique of the Ministry of Health } \\
\text { o Reinforcement of epidemiological surveillance throughout the } \\
\text { national territory, with particular emphasis on the country's } \\
\text { gateways; } \\
\text { Dissemination of information for health workers (sheets on } \\
\text { the disease to medical regions, health districts and all public } \\
\text { health facilities); } \\
\text { Starting Public information and awareness. }\end{array}$ \\
\hline 14 March 2020 & $\begin{array}{l}\text { - Closure of Schools and universities for three weeks } \\
\text { - Cancellation of public events } \\
\text { - Restriction of gatherings }\end{array}$ \\
\hline 18 March 2020 & $\begin{array}{l}\text { - Restrictions for a period of one month, of international flights } \\
\text { coming from France, Spain, Belgium, Italy and Portugal, Algeria and } \\
\text { Tunisia }\end{array}$ \\
\hline 20 March 2020 & $\begin{array}{l}\text { - Closure of international borders including all international and } \\
\text { domestic flights }\end{array}$ \\
\hline 24 March 2020 & $\begin{array}{l}\text { - State of Health emergency } \\
0 \text { Curfew from } 8 \text { P.m. to } 6 \text { a.m. } \\
0 \text { Intercity Movement restriction } \\
0 \text { Closure of schools and universities extended until further } \\
\text { notice. } \\
\text { Limited number of passengers in Public transport } \\
0 \text { Stay at home recommended } \\
\text { Income support to workers (at least } 70 \% \text { of salary to be paid) } \\
\text { o Creation of the Response and Solidarity Fund against the } \\
\text { effects of the coronavirus (FORCE-COVID-19) }\end{array}$ \\
\hline 11 April 2020 & $\begin{array}{l}\text { - Starting Food distribution Programme for } 1 \text { million people to address } \\
\text { the socio-economic effects of Covid-19 }\end{array}$ \\
\hline 17 April 2020 & - Mandatory wearing of protective mask in public places \\
\hline 20 April week 2020 & - Starting Tests for both symptomatic and asymptomatic \\
\hline 04 May 2020 & $\begin{array}{l}\text { - Restriction of the shops and markets opening to } 2 \text { days and } 3 \text { days } \\
\text { respectively }\end{array}$ \\
\hline 11 May 2020 & $\begin{array}{l}\text { - Relaxation of State of Health emergency } \\
0 \text { Curfew from } 9 \text { p.m. to } 5 \text { a.m. } \\
0 \text { Reopening of places of worship } \\
0 \text { Opening of the shops and markets extended to six days } \\
0 \text { Opening of schools for students in exam classes planned for } 2 \\
\text { June } 2020\end{array}$ \\
\hline 1 June 2020 & - Opening of schools for students in exam classes postponed \\
\hline
\end{tabular}
the COVID-19 pandemic, let us present an overview of the public decisions made by them during the first three months of the pandemic.

Senegalese Authorities responses to the COVID-19 Pandemic

Note: First confirmed case: 2 March 2020 

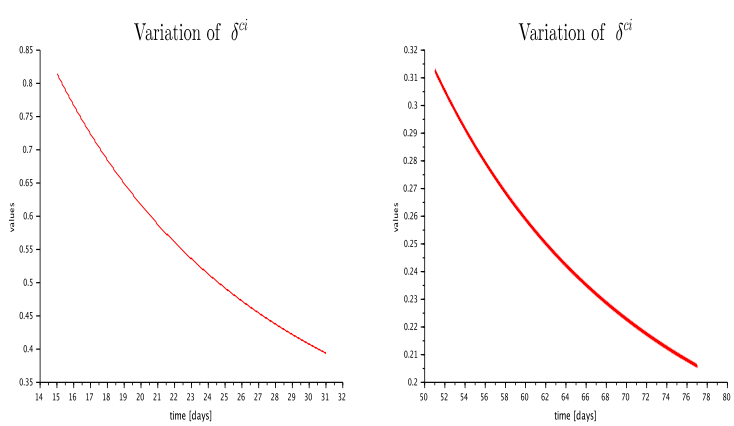

The infectivity rate $\delta^{c i}$ is calculated from the public data released by Senegalese health authorities. As presented in the graphs below, that critical epidemic parameter has decreased by $51.65 \%$ and $34.1 \%$ in Senegal in the two periods March 14 April 1 and April 21 - May 17, respectively. And, in accordance with the infectivity rate, the basic reproduction number $\mathcal{R}_{0}$ follows the same trend.

The decrease of the infectivity rate in the period March 14 - April 1, must be relatated to the decisions made by the authorities on March 14, mainly the closure of schools and universities. And the continuation of the decline in the period April 21 - May 17 is quite possibly due to the new measures taken, on the 20th and the 24th of March, notably the closure of senegalese international borders and the declaration of a state of public health emergency.

Recall that the infectivity rate $\delta^{c i}=\beta^{c i} c$, where the parameter $c$ is the rate of contacts per person per day, and $\beta^{c i}$ the probability to be infected from a contact. Therefore, these are two parameters which depend on the decisions made by public authorities and the degree of compliance of the population with them. In order to highlight the consequences of the definition and application of such measures, we simulate various scenarios.

In the figure below, the curve represents the status quo relative to the trend between April 21 and May 17. Notice that the data keep on fitting the curve until about May 27. Beyond that date, all of a sudden, the status quo is broken because the number of reported cases becomes much greater
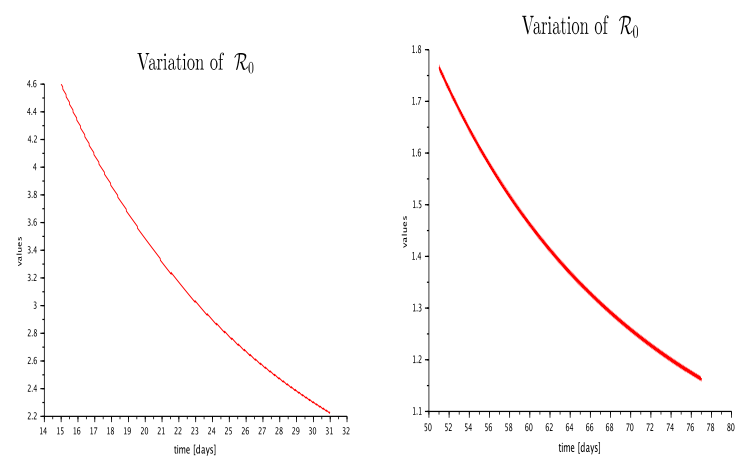

than the corresponding value of the curve. This phenomenon might be a delayed effect of the relaxation of the state of health emergency decided by the Senegalese authorities on May 11 (71st day after the beginning of the pandemic in Senegal).

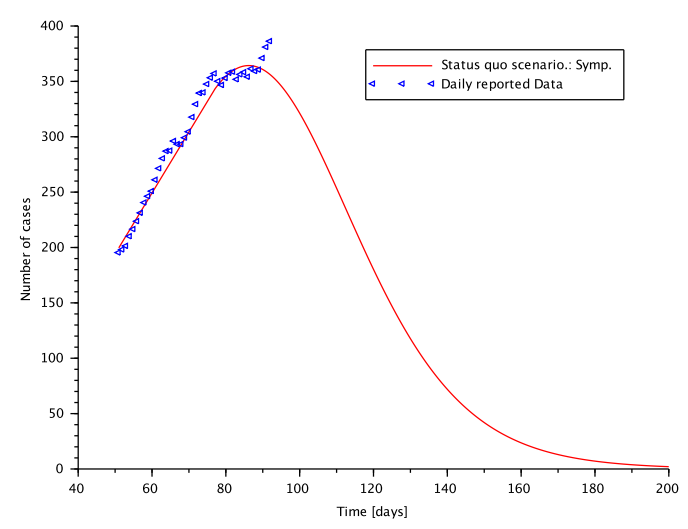

B. Post-fitting scenarios

Optimistic scenario: status quo and 50\% reduction of the contamination rate in one month

Regarding the figures below, we mention that if the trend at the 77th day of the pandemic was maintained, the peak would be reached around the 86th day. One can also notice that reducing the infectivity rate by $50 \%$ would only bring the peak forward by one week, and reduce the number of deaths by $20 \%$. 

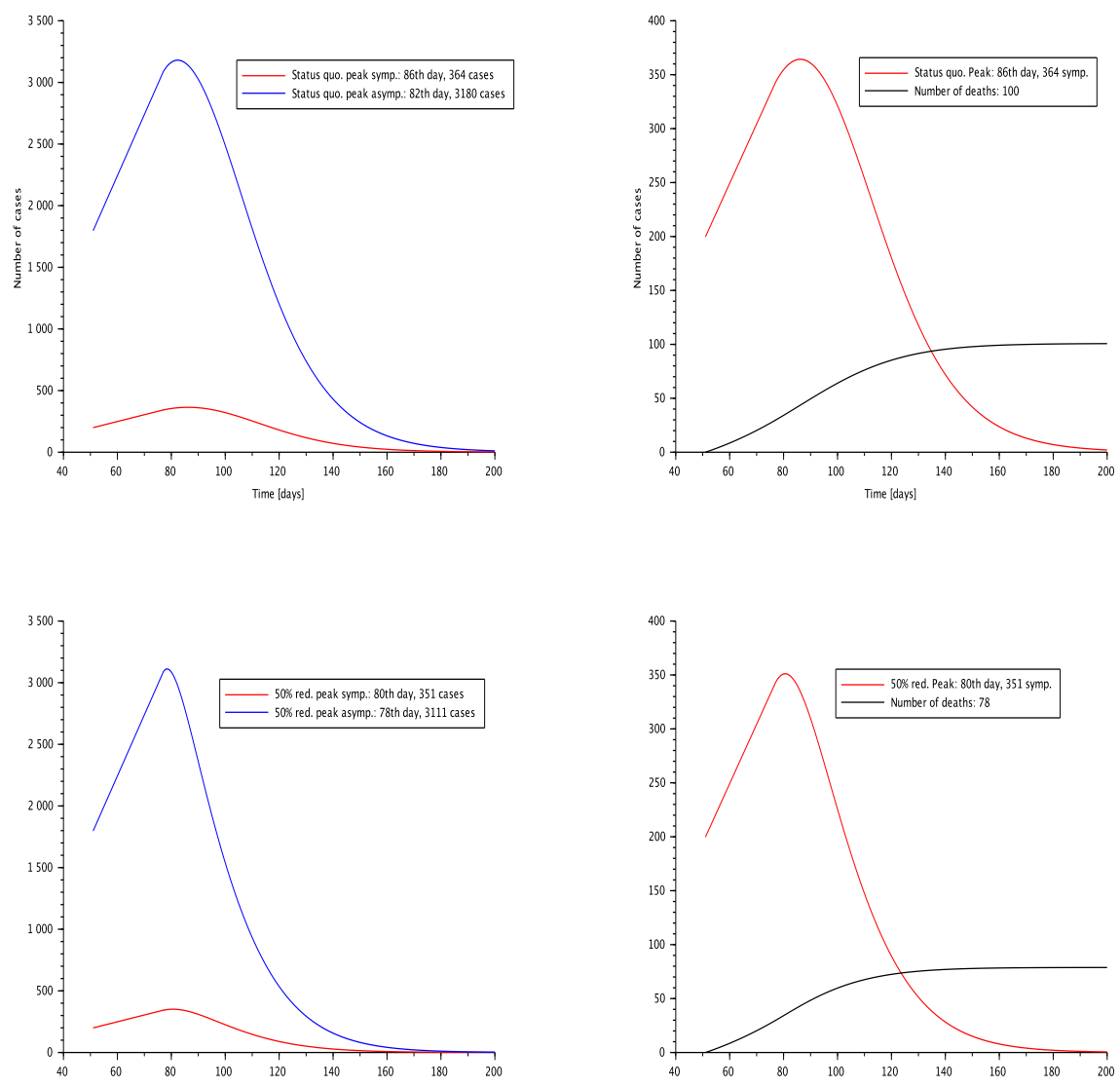

Note that the status quo is to stick to the tendency for the infectivity rate to exponentially decrease. In the sequel, we present simulations in which we gradually assume much less significant decrease of the infectivity rate. In simulating these scenarios, we consider two strategies: 1. protecting the people at risk, 2. not protecting the people at risk.

\section{Deviations from the status quo tendency}

The simulations we have performed give an evidence that the less significant the decrease of the infectivity rate is, the higher and the earlier the peak is. However, the price to pay is that the number of the deaths can be dramatically high. For instance, in case the infectivity rate is constant from the 77 th day, the number of deaths is around
77000. This is in line with the worst scenario for Africa characterized by no interventions and no awareness of African people presented by the United Nations Economic Commission for Africa in its report in April (see [14]). This report, exploiting the Imperial College COVID-19 Response Team simulations [4], predicts 3.3 million deaths in Africa in 2020, for this scenario. It's clear that Africa is not heading for this scenario, so far. Indeed, 3 months after the outbreak of the pandemic, the continent has less than 5 thousand deaths.

Such a favourable situation is possibly due to the youthfulness of the African population. In the case of Senegal, the median age of the population is 19.4 years whereas the world's is 30.6 years. Indeed, the Senegalese population is relatively 

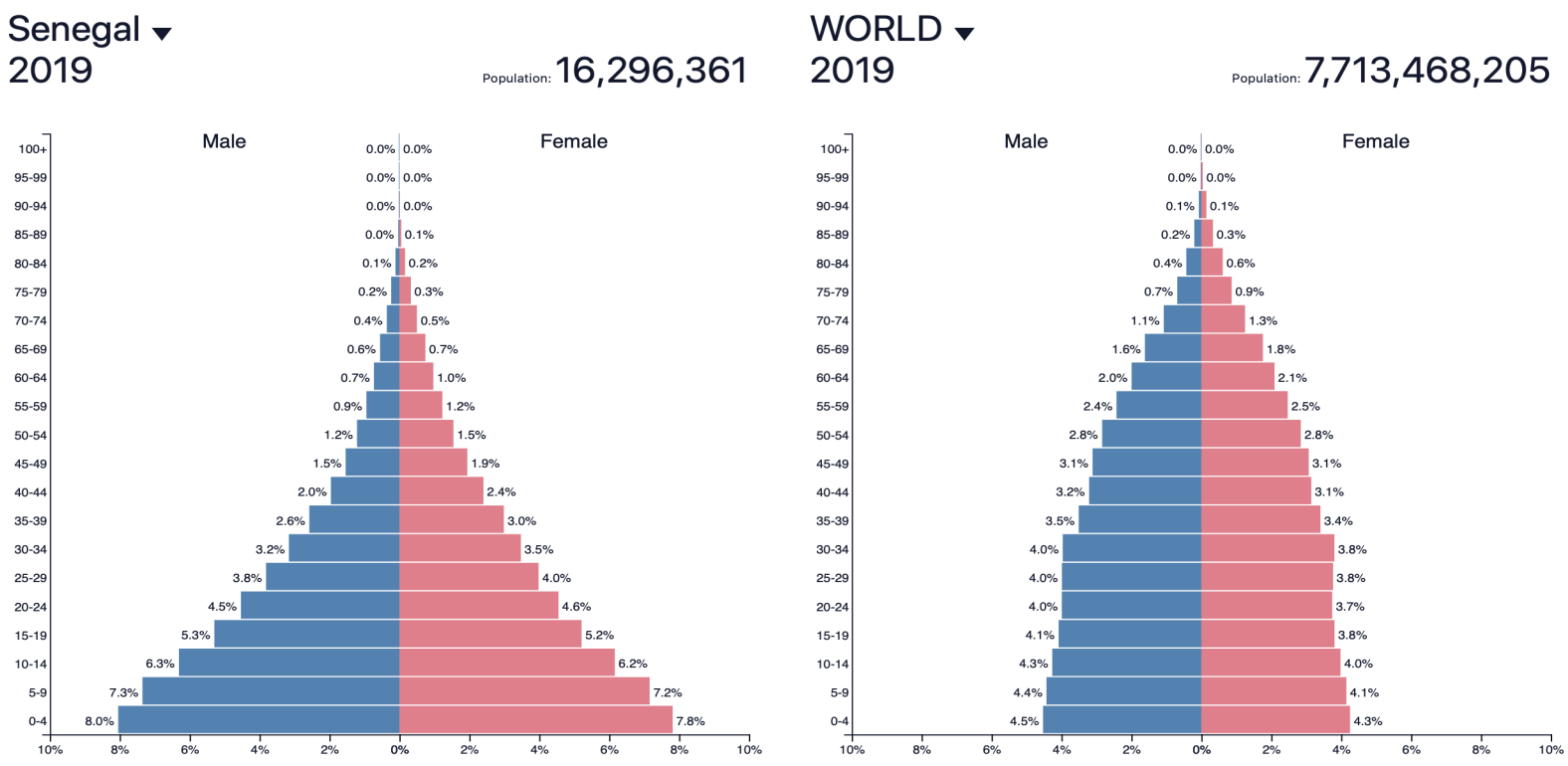

Source: https://www.populationpyramid.net/world/2019

young compared to most other countries'. See the age pyramids below.

\section{Youthfulness as an asset for collective immunity}

Considering the youthfulness of the Senegalese population brings us to add one more optimistic but realistic scenario to the 4 presented by United Nations Economic Commission for Africa in its report on COVID-19 [14]. The previsions of this report are inspired by the Imperial College COVID-19 Response Team simulation results [4], summarized in the table below.

By the way, regarding the resistance of young people to SARS-CoV-2, and the fact that the median age of Africa's population is only 19.7 years, the continent should define its specific strategy by aiming to collective immunity along with the protection of aged people and other people at risk. It's worth noticing that only 5.3\% of Africa's population are over 60 years old (see https://www.populationpyramid.net/africa/2019/), and that up to $94 \%$ of the deaths from the COVID-19 pandemic in the world among people are over 60 years old (see [9]).

The youthful profile of the population makes it easier for Senegal to attain collective immunity because it has less (aged) people at risk. This results, for example, in the following simulations with various levels of protection for people at risk, while the rest of the population are totally exposed. Indeed, considering the fact that people over 60 years age represent $4.8 \%$ of the population, with different rates of infectivity, we perform a simulation in which:

1) there is no protection for people at risk;

2) $90 \%$ of them are protected;

3) $99 \%$ of them are protected.

\section{Simulation for various disinfection rates}

The influence of the infected objects on the system can be brought out by tuning their infectivity rate and the disinfection parameter. Recall that the infectivity rate of objects is tightly related to hand washing and face touching. Below are some simulations related to three levels of disinfection, in the context of a $10 \%$ increase of the infectivity rate. Note that infected objects affect the magnitude 
M. Diaby, O. Diop, A. Konté, A. Sène, COVID-19 propagation mathematical modeling: the case of ...

26 March 2020

Imperial College COVID-19 Response Team

Table 1: Estimated impact of suppression strategies. The impact on infections and deaths over 250 days for two different suppression strategies triggered according to different thresholds for mortality incidence ( 0.2 and 1.6 deaths per 100,000 population per week).

\begin{tabular}{|c|c|c|c|c|c|c|}
\hline & \multicolumn{2}{|c|}{ Unmitigated Scenario } & \multicolumn{2}{|c|}{$\begin{array}{l}\text { Suppression at } 0.2 \text { deaths per } \\
100,000 \text { population per week }\end{array}$} & \multicolumn{2}{|c|}{$\begin{array}{l}\text { Suppression at } 1.6 \text { deaths per } \\
100,000 \text { population per week }\end{array}$} \\
\hline & Infections & Deaths & Infections & Deaths & Infections & Deaths \\
\hline East Asia \& Pacific & $2,117,131,000$ & $15,303,000$ & $92,544,000$ & 442,000 & $632,619,000$ & $3,315,000$ \\
\hline Europe \& Central Asia & $801,770,000$ & $7,276,000$ & $61,578,000$ & 279,000 & $257,706,000$ & $1,397,000$ \\
\hline Latin America \& Caribbean & $566,993,000$ & $3,194,000$ & $45,346,000$ & 158,000 & $186,595,000$ & 729,000 \\
\hline Middle East \& North Africa & $419,138,000$ & $1,700,000$ & $30,459,000$ & 113,000 & $152,262,000$ & 594,000 \\
\hline North America & $326,079,000$ & $2,981,000$ & $17,730,000$ & 92,000 & $90,529,000$ & 520,000 \\
\hline South Asia & $1,737,766,000$ & $7,687,000$ & $111,703,000$ & 475,000 & $629,164,000$ & $2,693,000$ \\
\hline Sub-Saharan Africa & $1,044,858,000$ & $2,483,000$ & $110,164,000$ & 298,000 & $454,968,000$ & $1,204,000$ \\
\hline Total & $7,013,734,000$ & $40,624,000$ & $469,523,000$ & $1,858,000$ & $2,403,843,000$ & $10,452,000$ \\
\hline
\end{tabular}

Table 1. COVID-19 world forecasts

\begin{tabular}{|c|c|c|c|c|c|c|c|c|c|c|c|c|}
\hline \multirow[b]{2}{*}{ Protection } & \multicolumn{3}{|c|}{$\begin{array}{l}\text { Infectivity } \\
+\mathbf{2 0 0} \%\end{array}$} & \multicolumn{3}{|c|}{$\begin{array}{l}\text { Infectivity } \\
\quad+100 \%\end{array}$} & \multicolumn{3}{|c|}{$\begin{array}{l}\text { Infectivity } \\
\quad+\mathbf{5 0} \%\end{array}$} & \multicolumn{3}{|c|}{$\begin{array}{l}\text { Infectivity } \\
+25 \%\end{array}$} \\
\hline & $0 \%$ & $90 \%$ & $99 \%$ & $0 \%$ & $90 \%$ & $99 \%$ & $0 \%$ & $90 \%$ & $99 \%$ & $0 \%$ & $90 \%$ & $99 \%$ \\
\hline $\begin{array}{l}\text { Date of the } \\
\text { peak }\end{array}$ & $\begin{array}{c}08-15 \\
\text { July } \\
2020\end{array}$ & $\begin{array}{c}10-18 \\
\text { July } \\
2020\end{array}$ & $\begin{array}{c}10-18 \\
\text { July } \\
2020\end{array}$ & \begin{tabular}{|c|} 
July 28 \\
- Aug \\
042020
\end{tabular} & \begin{tabular}{|c|} 
July 31 \\
- Aug \\
072020
\end{tabular} & \begin{tabular}{|c} 
July 31 \\
- Aug \\
07 2020
\end{tabular} & $\begin{array}{c}16-24 \\
\text { Aug } \\
2020\end{array}$ & $\begin{array}{l}20-28 \\
\text { Aug } \\
2020\end{array}$ & $\begin{array}{c}20-28 \\
\text { Aug } \\
2020\end{array}$ & $\begin{array}{c}03-10 \\
\text { Sept } \\
2020\end{array}$ & $\begin{array}{r}08-15 \\
\text { Sept } \\
2020\end{array}$ & $\begin{array}{l}07-15 \\
\text { Sept } \\
2020\end{array}$ \\
\hline $\begin{array}{l}\text { Asymptom } \\
\text { atics peak } \\
\text { value }\end{array}$ & \begin{tabular}{|c|}
4.61 \\
millions
\end{tabular} & $\begin{array}{c}4.49 \\
\text { millions }\end{array}$ & \begin{tabular}{|c|}
4.49 \\
millions
\end{tabular} & $\begin{array}{c}3.10 \\
\text { millions }\end{array}$ & $\begin{array}{c}\mathbf{3} \\
\text { millions }\end{array}$ & $\begin{array}{c}3.01 \\
\text { millions }\end{array}$ & $\begin{array}{c}2.24 \\
\text { millions }\end{array}$ & $\begin{array}{c}2.16 \\
\text { millions }\end{array}$ & \begin{tabular}{|c|}
2.16 \\
millions
\end{tabular} & $\begin{array}{c}1.77 \\
\text { millions }\end{array}$ & \begin{tabular}{c|}
1.70 \\
millions
\end{tabular} & $\begin{array}{c}1.70 \\
\text { millions }\end{array}$ \\
\hline $\begin{array}{l}\text { Symptomat } \\
\text { ics peak } \\
\text { value }\end{array}$ & 468955 & 471451 & 472449 & 341131 & 341077 & $\mathbf{3 4 3 4 3 8}$ & 257548 & 256148 & 26993 & 208074 & 205979 & 206550 \\
\hline Average R0 & 4.259 & 4.270 & 4.267 & 2.940 & 2.944 & 2.958 & 2.27 & 2.27 & 2.27 & 1.919 & 1.920 & 1.920 \\
\hline $\begin{array}{l}\text { Number of } \\
\text { deaths }\end{array}$ & 93590 & 9644 & 993 & 91122 & 9372 & 967 & 87247 & 8954 & 924 & 83549 & 8556 & 885 \\
\hline $\begin{array}{l}\text { Number of } \\
\text { immune }\end{array}$ & \begin{tabular}{|c|}
15.59 \\
millions
\end{tabular} & $\begin{array}{c}15.65 \\
\text { millions }\end{array}$ & $\begin{array}{c}15.66 \\
\text { millions }\end{array}$ & $\begin{array}{c}14.86 \\
\text { millions }\end{array}$ & $\begin{array}{c}14.88 \\
\text { millions }\end{array}$ & $\begin{array}{c}14.91 \\
\text { millions }\end{array}$ & $\begin{array}{c}14.06 \\
\text { millions }\end{array}$ & $\begin{array}{c}14.06 \\
\text { millions }\end{array}$ & $\begin{array}{c}14.07 \\
\text { millions }\end{array}$ & $\begin{array}{c}13.39 \\
\text { millions }\end{array}$ & $\begin{array}{c}13.35 \\
\text { millions }\end{array}$ & $\begin{array}{c}13.37 \\
\text { millions }\end{array}$ \\
\hline
\end{tabular}

Table 2. COVID-19 Senegalese forecasts: collective immunity 
M. Diaby, O. Diop, A. Konté, A. Sène, COVID-19 propagation mathematical modeling: the case of ...

\begin{tabular}{|c|c|c|c|c|c|c|c|c|c|c|c|c|}
\hline \multirow[b]{2}{*}{ Protection } & \multicolumn{3}{|c|}{$\begin{array}{c}\text { Infectivity } \\
00 \%\end{array}$} & \multicolumn{3}{|c|}{$\begin{array}{c}\text { Infectivity } \\
-25 \%\end{array}$} & \multicolumn{3}{|c|}{$\begin{array}{c}\text { Infectivity } \\
-50 \%\end{array}$} & \multicolumn{3}{|c|}{$\begin{array}{c}\text { Infectivity } \\
-\mathbf{8 5 \%}\end{array}$} \\
\hline & $0 \%$ & $90 \%$ & $99 \%$ & $0 \%$ & $90 \%$ & $99 \%$ & $0 \%$ & $90 \%$ & $99 \%$ & $0 \%$ & 90\% & $99 \%$ \\
\hline $\begin{array}{l}\text { Date of the } \\
\text { peak }\end{array}$ & $\begin{array}{c}01-08 \\
\text { Oct } \\
2020\end{array}$ & $\begin{array}{c}08-09 \\
\text { Oct } \\
2020\end{array}$ & $\begin{array}{c}08-15 \\
\text { Oct } \\
2020\end{array}$ & $\begin{array}{c}27 \text { Nov- } \\
04 \text { Dec } \\
2020\end{array}$ & $\begin{array}{c}08-16 \\
\text { Dec } \\
2020\end{array}$ & $\begin{array}{c}08-15 \\
\text { Dec } \\
2020\end{array}$ & $\begin{array}{c}12-18 \\
\text { June } \\
2021\end{array}$ & $\begin{array}{c}21-27 \\
\text { July } \\
2021\end{array}$ & $\begin{array}{c}19-26 \\
\text { July } \\
2021\end{array}$ & $\begin{array}{l}17-19 \\
\text { May } \\
2020\end{array}$ & \begin{tabular}{|c|}
$17-19$ \\
May \\
2020 \\
\end{tabular} & $\begin{array}{c}17-19 \\
\text { May } \\
2020\end{array}$ \\
\hline $\begin{array}{l}\text { Asymptomatics } \\
\text { peak value }\end{array}$ & \begin{tabular}{|c|}
1.28 \\
millions
\end{tabular} & $\begin{array}{c}1.22 \\
\text { millions }\end{array}$ & $\begin{array}{c}1.22 \\
\text { millions }\end{array}$ & 771768 & 722359 & 723173 & 246063 & 211936 & 213033 & 3102 & 3095 & 3095 \\
\hline $\begin{array}{l}\text { Symptomatics } \\
\text { peak value }\end{array}$ & 153472 & 150703 & 151179 & 93635 & 90293 & 90657 & 30185 & 26776 & 26993 & 348 & 351 & 351 \\
\hline Average R0 & 1.559 & 1.560 & 1.560 & 1.189 & 1.190 & 1.190 & 0.807 & 0.807 & 0.807 & 0.334 & 0.336 & 0.336 \\
\hline $\begin{array}{l}\text { Number of } \\
\text { deaths }\end{array}$ & 77478 & 7904 & 819 & 66556 & 6732 & 702 & 42662 & 4152 & 444 & 79 & 34 & 30 \\
\hline $\begin{array}{l}\text { Number of } \\
\text { immune }\end{array}$ & $\begin{array}{c}12.35 \\
\text { millions }\end{array}$ & \begin{tabular}{|c|}
12.27 \\
millions
\end{tabular} & \begin{tabular}{|c|}
12.28 \\
millions
\end{tabular} & \begin{tabular}{|c|}
10.55 \\
millions
\end{tabular} & \begin{tabular}{|c|}
10.39 \\
millions
\end{tabular} & \begin{tabular}{|c|}
10.40 \\
millions
\end{tabular} & \begin{tabular}{|c|}
6.73 \\
millions
\end{tabular} & \begin{tabular}{|c|}
6.36 \\
millions
\end{tabular} & \begin{tabular}{|c|}
6.38 \\
millions
\end{tabular} & 12280 & 12137 & \begin{tabular}{|l|l|}
12148 \\
\end{tabular} \\
\hline
\end{tabular}

Table 3. COVID-19 Senegalese previsions: reinforcing barrier measures
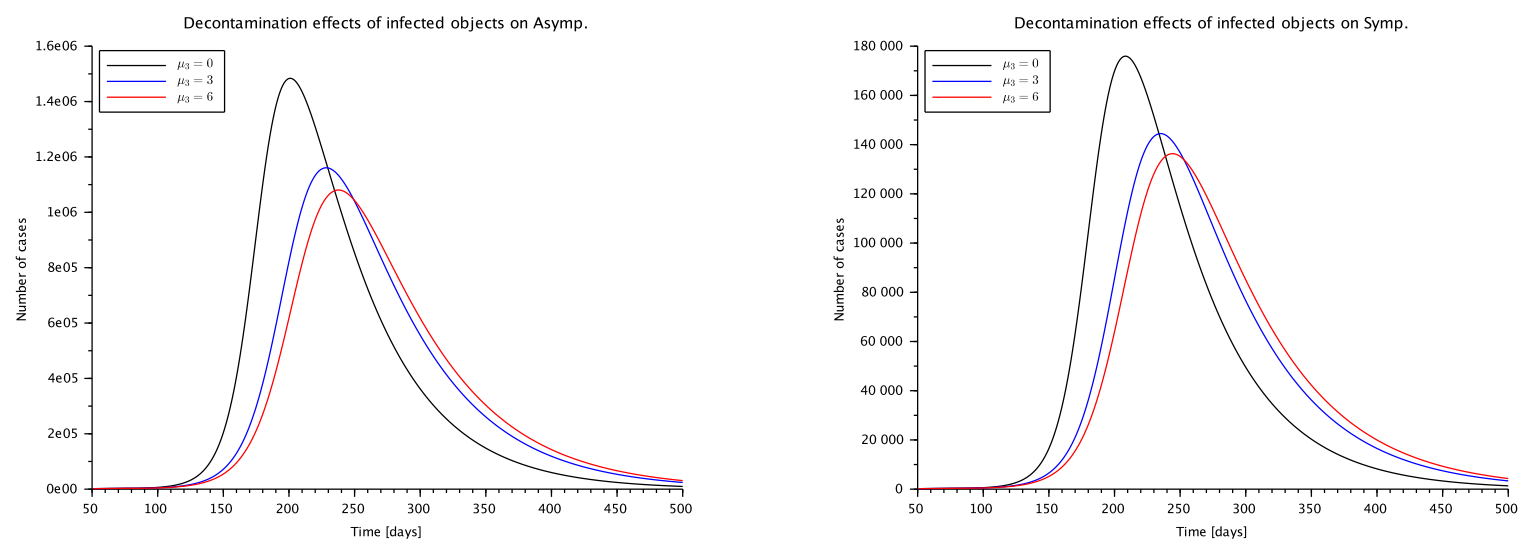

Fig. 1: Number of infected objects

of the peak and its date of occurence. This is an evidence of the relevancy of considering the objects compartment.

\section{CONClusion}

In order to comply with Senegalese public health authorities response to the COVID-19 pandemic, we have built a 6-compartment model including a quarantined people compartment. An infected objects compartment is considered so as not to neglect their impact in the propagation of the disease. The equation governing the number of objects has received a special treatment by imposing the decrease of the contamination rates of objects as the number of infected objects increases. This condition ensures that no object can be counted as infected while it is infected. Recall that $B_{s}$ and $B_{a}$ stand for the maximum number of objects per day a symptomatic and asymptomatic can infect, respectively. The latter could hardly make sense 
M. Diaby, O. Diop, A. Konté, A. Sène, COVID-19 propagation mathematical modeling: the case of ...

since the number of all objects is infinity.

Then, in terms of analysis of the ODE system, one easily proves the boundedness of solutions, and by the classical decomposition of the system, the basic reproduction number $\mathcal{R}_{0}$ is formally calculated.

The last part of this work is devoted to numerical simulation of different scenarios, from the most optimistic to the most pessimistic in terms of day of occurence and magnitude of the peak, and number of deaths. Based on the official daily data released by senegalese health authorities, from the 15th to the 77 th day after the burst of the pandemic, by fitting, we estimate epidemiologic parameters such as the infection and contact rates. Then, from the 77th day of the pandemic, we have simulated the different possible scenarios depending on the behavior of the population. The scenarios presented allow to quantify the impact of the application of the barrier measures taken by public authorities. For instance, the observation of physical distancing measures, the wearing of masks, hand washing and objects disinfection are variation factors of the infectivity rate. Here are a few observations we have made:

- If the status quo was maintained from May 17 on, say the infectivity rate decreases with the same velocity as the period of time April 21 - May 17 2020, the peak would be attained about May 26.

- There is a deviation from the trend of the period April 21 - May 17 leading to a higher and later peak.

- The gradual increase of the infectivity rate allows to bring out advantages and drawbacks of collective immunity. The observation of the different scenarios shows that increasing the infectivity rate without accompanying measures: brings the peak earlier; puts the peak higher; causes more deaths (see Tables 2 and 3).

- The ideal scenario in terms of number of deaths, early occurence of the peak, and collective immunity, consists on:

- taking measures for protecting only the aged people and all the people with comorbidity, from the virus.

- cancelling all other barrier measures for attaining collective immunity,

- The decontamination of objects affects significantly the magnitude and the date of occurence of the peak.

\section{ACKNOWLEDGMENT}

The authors would like to thank Virtual University of Senegal via PIED ( Pôle d'Innovation et d'Expertise pour le Développement) project for his support.

\section{REFERENCES}

[1] B. E. Ainseba, C. Benosman and P. Magal, $A$ model for ovine brucellosis incorporating direct and indirect transmission, Journal of Biological Dynamics, Vol. 4, No. 1, January 2010, 2-11.

[2] N. VAn Doremalen, T. Bushmaker, D. H. Morris, M. G. Holbrook, A. Gamble, B. N. Williamson, A. TAmin, J. L. Harcourt, N. J. Thornburg, S. I. Gerber, J. O. Lloyd-Smith, E. De Wit, V. J. MUnSTER, Aerosol and Surface Stability of SARS-CoV2 as Compared with SARS-CoV-1, (April 16, 2020), N. Engl. J. Med., 2020; 382:1564-1567, DOI: 10.1056/NEJMc2004973.

[3] Q. Griette, P. Magal and O. Seydi, Unreported cases for Age Dependent COVID-19 Outbreak in Japan, MedRxiv (2020) doi:https://doi.org/10.1101/2020.05.07. 20093807

[4] Imperial College COVID-19 Response TeAm, Report 12: The Global Impact of COVID-19 and Strategies for Mitigation and Suppression, DOI: https://doi.org/10.25561/77735, Page 1-18, 26 March 2020.

[5] Z. LiU, P. Magal, O. Seydi And G. Webb, Predicting the cumulative number of cases for the COVID19 epidemic in China from early data, Mathematical Biosciences and Engineering 17(4) (2020), 3040-3051. https://doi.org/10.3934/mbe.2020172

[6] Z. LiU, P. MAGAl, O. SEYDi AND G. WebB, Understanding unreported cases in the 2019-nCov epidemic outbreak in Wuhan, China, and the importance of major public health interventions, Biology 9(3) (2020), 50. https://doi.org/10.3390/biology9030050

[7] Z. LiU, P. Magal, O. Seydi And G. WebB, A COVID19 epidemic model with latency period, Infectious Disease Modelling 5 (2020). https://doi.org/10.1016/j.idm. 2020.03.003

[8] Z. LiU, P. Magal, O. Seydi, And G. WebB, A model to predict COVID-19 epidemics with applications to South Korea, Italy, and Spain, SIAM News (2020). 
M. Diaby, O. Diop, A. Konté, A. Sène, COVID-19 propagation mathematical modeling: the case of ...

[13] B. TAng, X. Wang, Q. Li, N. L. BragazZI, S. TANG, Y. XIAO, J. WU, Estimation of the transmission risk of 2019-nCov and its implication for public health interventions, (January 24, 2020). Available at SSRN: https://ssrn.com/abstract $=3525558$ or http://dx.doi.org/10.2139/ssrn.3525558.

[14] United NATIONS ECONOMIC COMMISSION FOR AFrICA REPORT, COVID-19 in Africa Protecting Lives and Economies, April 2020.

[15] Wang, Jingyuan and Tang, Ke and Feng, KaI AND Lin, XIN AND LV, WEIFENG AND CHEN, Kun AND Wang, FEI, High Temperature and High Humidity Reduce the Transmission of COVID-19 (March 9, 2020). Available at SSRN: https://ssrn.com/abstract $=3551767$ or http://dx.doi.org/10.2139/ssrn.3551767.

[16] Z. ZhaO, X. Li, F. LiU, G. ZhU, C. MA, L. WANG, Prediction of the COVID-19 spread in African countries and implications for prevention and control: A case study in South Africa, Egypt, Algeria, Nigeria, Senegal and Kenya, Science of the Total Environment 729 (2020) 138959.

[17] P. ZuccotTi, Every Thing We Touch: A 24-Hour Inventory of Our Lives, Paperback, 12 Nov 2015, Published by Viking - Penguin Random House.
[9] F. NATALE, D. GHIO, D. TARCHI, A. GOUJON, A. CONTE, COVID-19 Cases and Case Fatality Rate by age, European Commission, Knowledge for policy, 4 MAY 2020.

[10] Y. L. A. Kwok, J. Gralton, M-L McLaws, Face touching: A frequent habit that has implications for hand hygiene, American Journal of Infection Control 43 (2015) 112-4.

[11] A. Le Nestour, S. Mbaye, L. Moscoviz, Enquête téléphonique sur la crise du COVID-19 au Sénégal, Center for Global Development (CGD, https://www.cgdev.org) and the Centre de recherche pour le développement économique et social (CRDES, http://crdes.sn), April 2020.

[12] C. B. Ogbunugafor, M. Miller-Dickson, V. A. Meszaros, L. M. Gomez, A. L. Murillo, AND S. V. SCARPINO, The intensity of COVID19 outbreaks is modulated by SARS-CoV-2 freeliving survival and environmental transmission, https://doi.org/10.1101/2020.05.04.20090092, Preprint. 